\title{
Geoscience Engagement in Global Development Frameworks
}

\author{
JOEL C. GILL \\ British Geological Survey, Environmental Science Centre, \\ Nicker Hill, Keyworth, Nottingham, NG12 5GG, UK \\ Geology for Global Development, UK \\ joell@bgs.ac.uk \\ FLORENCE BULLOUGH \\ Geological Society of London, Burlington House, \\ Piccadilly, London, W1J 0BG, UK \\ florence.bullough@geolsoc.org.uk
}

\begin{abstract}
During 2015, the international community agreed three socio-environmental global development frameworks, the: (i) Sustainable Development Goals, (ii) Sendai Framework for Disaster Risk Reduction, and (iii) Paris Agreement on Climate Change. Each corresponds to important interactions between environmental processes and society. Here we synthesize the role of geoscientists in the delivery of each framework, and explore the meaning of and justification for increased geoscience engagement (active participation). We first demonstrate that geoscience is fundamental to successfully achieving the objectives of each framework. We characterize four types of geoscience engagement (framework design, promotion, implementation, and monitoring and evaluation), with examples within the scope of the geoscience community. In the context of this characterization, we discuss: (i) our ethical responsibility to engage with these frameworks, noting the emphasis on societal cooperation within the Cape Town Statement on Geoethics; and (ii) the need for increased and higher quality engagement, including an improved understanding of the science-policy-practice interface. Facilitating increased engagement is necessary if we are to maximize geoscience's positive impact on global development.
\end{abstract}

\section{INTRODUCTION}

$\mathrm{T}$ The agreement of three global development frameworks in 2015 reflects 'a global consensus that business as usual is no option any longer, that changing the development trajectory is necessary' (Spangenberg, 2016, p.1). The UN Sustainable Development Goals (SDGs), Sendai Framework for Disaster Risk Reduction (SFDRR) and COP21 Paris Climate Change Agreement (Paris Agreement) will be at the forefront of national and international policy discourse for the next 15 years. Collectively they aim to shape the strategies that guide economic growth, human welfare, access to natural resources, and environmental management. Each of the SDGs, SFDRR, and Paris Agreement relates to the interaction of human activities with the natural environment. Advances in science and technology, including geoscience, are central to each framework (e.g., Lubchenco et al., 2015; Aitsi-Selmi et al., 2016; Boucher et al., 2016; Gluckman, 2016; Gill, 2017). For example, managing natural resources, characterizing natural hazards, or modelling future climate all require multi-scale (spatial and temporal) understanding of Earth materials and/or processes. This requirement for geoscience input presents an opportunity for the geoscience community. It also places 
upon us a social responsibility to engage, which we define to mean 'actively participating in framework design, promotion, implementation, monitoring and evaluation'. Scientific business as usual, however, will not be sufficient, with changes to geoscience practice required for successful engagement (Lubchenco et al., 2015).

In this paper, we describe each global development framework and opportunities for geoscientists to help deliver their objectives (Sections 2-4). We then discuss engagement by geoscientists, reflecting upon types of engagement, our ethical responsibility to engage, catalyzing increased engagement, and characterizing effective engagement (Section 5).

\section{SUSTAINABLE DEVELOPMENT GOALS}

In September 2015, member states of the United Nations formally adopted the Sustainable Development Goals (SDGs), an ambitious set of 17 goals and 169 targets (UN, 2015a). The SDGs aim to eradicate global poverty, end unsustainable consumption patterns, and facilitate sustained and inclusive economic growth, social development, and environmental protection over a 15-year period, 2015-2030 (UN, 2015a).

The SDGs have been described as 'science intensive' (Gluckman, 2016), with their environmental focus meaning geoscience is essential to their success (Lubchenco et al., 2015). Gill (2017) produced a matrix, which illustrates the role of geoscience in the SDGs (Fig. 1). The matrix was populated by analyzing the text of the specific SDG sub-goals and targets, identifying links between SDG requirements and geoscience. Interconnections between many SDGs (Nilsson et al., 2016) results in this approach giving a conservative estimate of the true impact of geoscience interventions. For example, goals on education (SDG 4) and gender equality (SDG 5) do not specifically refer to access to water/sanitation (SDG 6), but increased access to water/sanitation can support both. Fig. 1 shows a role for geoscience within all 17 of the SDGs. Contributions will be required from all sectors and sub-disciplines of geoscience, in- cluding those working in research, industry, the public sector and civil society.

Examples of geoscience activities helping to deliver the SDGs include research projects, industry engagement, and civil society activities. We provide specific examples in Section 5.

\section{SENDAI FRAMEWORK FOR DISASTER RISK REDUCTION (SFDRR) 2015-30}

The SFDRR was adopted at the 3rd UN World Conference on DRR in March 2015, supported by the UN Office for Disaster Risk Reduction (UNISDR). Through its implementation, the SFDRR aims to reduce substantially disaster risk and losses in all forms (UNISDR, 2015).

The SFDRR includes four Priorities for Action (PfA), with a 2016 UNISDR conference demonstrating the scope for science and technology in delivering each (Aitsi-Selmi et al., 2016). We introduce each PfA in Table 1, with a description of geo-sciences' role and examples of engagement. Underpinning the four PfA of the SFDRR are 13 guiding principles, many of which require geoscience input. For example, one guiding principle requests that decisionmaking use a 'multi-hazard approach'. UNISDR (2017) defines multi-hazard as considering interrelationships between natural hazards, including hazardous events occurring simultaneously, in cascades, or cumulatively over time. Geoscientists have experience in contributing to the understanding and communication of multi-hazard dynamics. For example, following the 2015 M7.8 earthquake in Nepal, the British Geological Survey compiled inventories of triggered landslides (BGS, 2017a).

Inventories, and associated maps, demonstrate where landslides block rivers (potentially triggering floods), and can be used by organizations responding to disasters. Other guiding principles can inform change within the geoscience community, helping to improve engagement in the SFDRR. For example, research collaborations should reflect on the principle 'international cooperation to be effective, meaningful and strong'. 


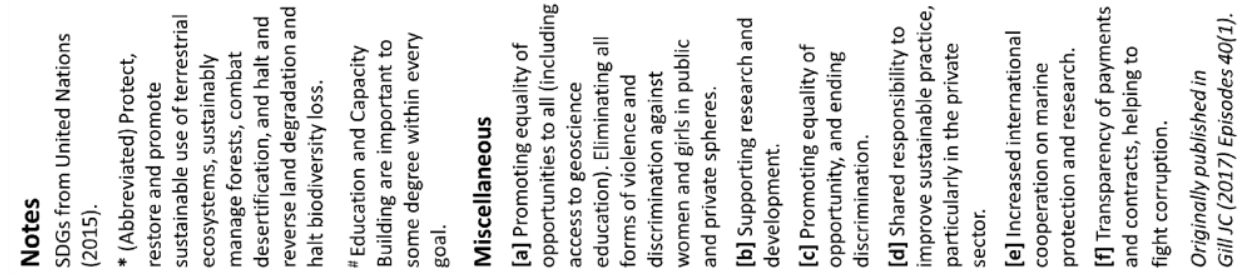

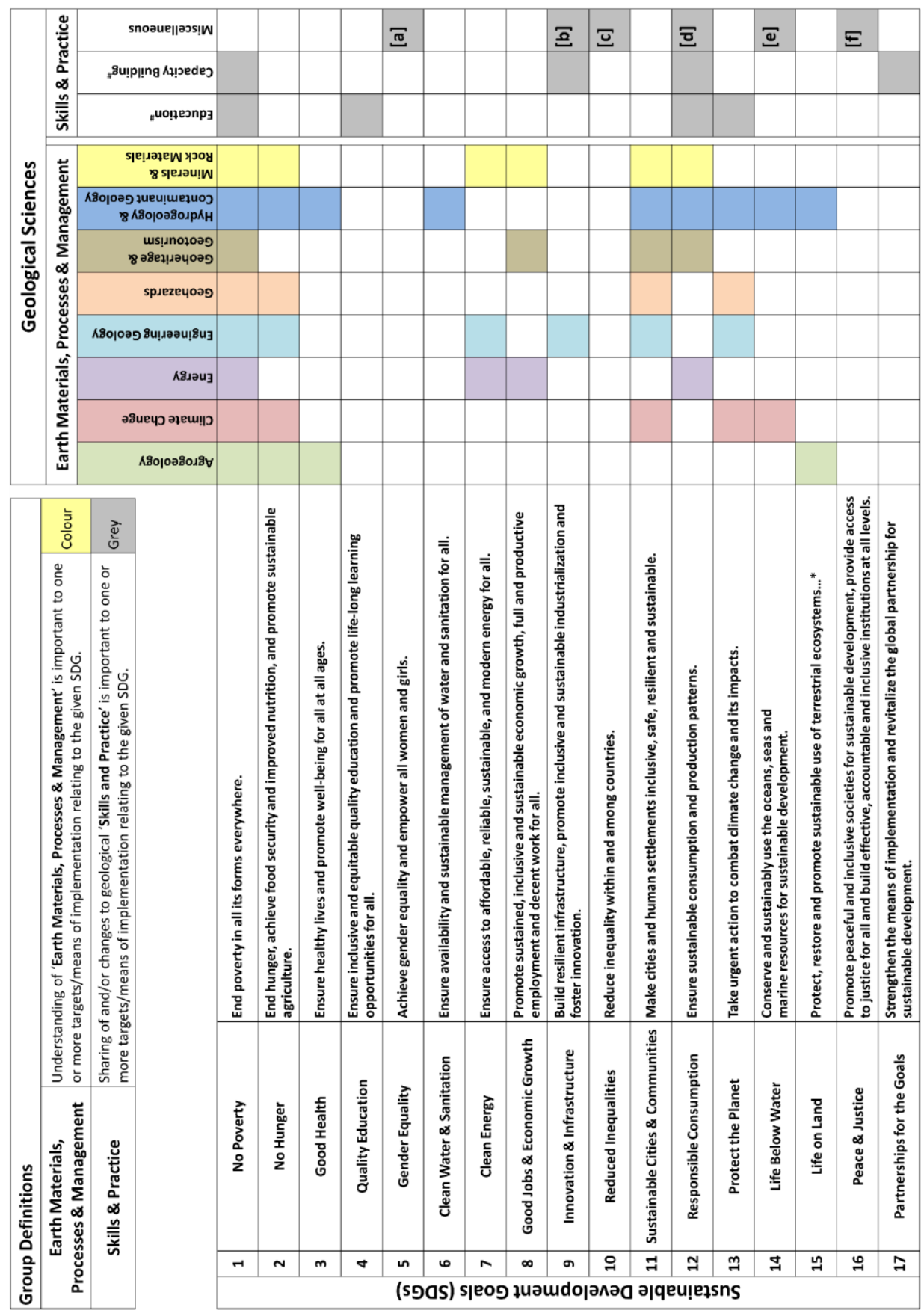

Figure 1: A matrix highlighting the role of geoscientists in helping to achieve the SDGs (Gill, 2017). 
Table 1: Geoscience and the Sendai Framework for Disaster Risk Reduction.

\begin{tabular}{|c|c|c|}
\hline $\begin{array}{l}\text { Priority for } \\
\text { Action (PfA) }\end{array}$ & Description and Use of Geoscience & Example Output \\
\hline $\begin{array}{l}\text { 1. Understanding } \\
\text { disaster risk }\end{array}$ & $\begin{array}{l}\text { Research on earthquakes, volcanic eruptions, tsunamis, } \\
\text { landslides, subsidence, and other hazards addresses this } \\
\text { priority. PfA- } 1 \text { also requests comprehensive surveys of } \\
\text { multi-hazard disaster risk, regional assessments and maps, } \\
\text { and enhanced access to and support for long-term multi- } \\
\text { hazard research. }\end{array}$ & $\begin{array}{l}\text { An interrelated } \\
\text { hazards approach to } \\
\text { anticipating evolv- } \\
\text { ing risk (Duncan et } \\
\text { al., 2016). }\end{array}$ \\
\hline $\begin{array}{l}\text { 2. Strengthening } \\
\text { disaster risk gov- } \\
\text { ernance to manage } \\
\text { disaster risk }\end{array}$ & $\begin{array}{l}\text { Geoscience information informs laws, regulations and pol- } \\
\text { icy tools. For example, understanding ground conditions is } \\
\text { a necessary input to building codes. PfA- } 2 \text { also emphasizes } \\
\text { the development of strategies to strengthen environmental } \\
\text { resilience, environmental and resource management } \\
\text { standards, and policies to prevent settlement in disaster- } \\
\text { risk prone zones. }\end{array}$ & $\begin{array}{l}\text { Earthquake science } \\
\text { in DRR policy and } \\
\text { practice in Nepal } \\
\text { (Oven et al., 2016). }\end{array}$ \\
\hline $\begin{array}{l}\text { 3. Investing in dis- } \\
\text { aster risk reduction } \\
\text { for resilience }\end{array}$ & $\begin{array}{l}\text { Resilience is enhanced through investment in both struc- } \\
\text { tural and non-structural measures. For example, retrofit- } \\
\text { ting critical infrastructure to the effects of earthquakes } \\
\text { (structural), and ensuring coherence of DRR and urban de- } \\
\text { velopment strategies (non-structural). PfA-3 seeks to main- } \\
\text { stream disaster risk assessment into land-use policy devel- } \\
\text { opment and implementation. It also encourages coopera- } \\
\text { tion between scientific networks and the private sector to } \\
\text { develop new products/services to reduce risk. }\end{array}$ & $\begin{array}{l}\text { Setting, measuring } \\
\text { and monitoring tar- } \\
\text { gets for reducing } \\
\text { disaster risk (Mitch- } \\
\text { ell et al., 2014), with } \\
\text { comment on insur- } \\
\text { ance and catastro- } \\
\text { phe modelling. }\end{array}$ \\
\hline $\begin{array}{l}\text { 4. Enhancing disas- } \\
\text { ter preparedness for } \\
\text { effective response } \\
\text { and to 'Build Back } \\
\text { Better' in recovery, } \\
\text { rehabilitation, and } \\
\text { reconstruction }\end{array}$ & $\begin{array}{l}\text { PfA-4 requests development and maintenance of people- } \\
\text { centered multi-hazard, multisectoral forecasting, early } \\
\text { warning systems, and hazard-monitoring communications. } \\
\text { Geoscience information will need integrating with appro- } \\
\text { priate knowledge in communications, development, and } \\
\text { psychology. PfA-4 also encourages preparedness, response } \\
\text { and recovery exercises, and sharing of resources. }\end{array}$ & $\begin{array}{l}\text { Using video games } \\
\text { for volcanic hazard } \\
\text { education and } \\
\text { communication } \\
\text { (Mani et al., 2016). }\end{array}$ \\
\hline
\end{tabular}

${ }^{1}$ See UNISDR (2015) for full description, and lists of local/national and regional/global objectives.

\section{PARIS CLIMATE CHANGE AGREEMENT}

Geoscience has significantly contributed to our understanding of anthropogenic climate change. For example, evidence of climate change in the geological record forms an important, independent evidence base for anthropogenic climate change (GSL, 2010). The Paris Agreement, published at the end of the 21st Conference of the Parties (COP21) in De- cember 2015, secured a legislative agreement with a long-term goal to limit climate change to well below $2^{\circ} \mathrm{C}$ above pre-industrial averages (UN, 2015b). At the time of writing 132 parties ratified this agreement. The Paris Agreement consists of an opening statement and 29 'Articles' which detail the component parts of the agreement. Many Articles refer to requirements for which geoscience expertise and capacity are essential, as described in Table 2. 
Table 2: Geoscience and COP21: The role of geoscience in delivering the agreement.

\begin{tabular}{l} 
Relevant Articles (UN, 2015b) \\
\hline Article 2.1(a): 'Holding the in- \\
crease in the global average temper- \\
ature to well below $2^{\circ} \mathrm{C}$ above pre- \\
industrial levels and to pursue ef- \\
forts to limit the temperature in- \\
crease to $1.5^{\circ} \mathrm{C}$ above pre-industrial \\
levels.' \\
Article $\mathbf{2 . 1 ( b ) : ~ ' I n c r e a s i n g ~ t h e ~ a b i l - ~}$ \\
ity to adapt to the adverse impacts \\
of climate change and foster resili- \\
ence...in a manner that does not \\
threaten food production.'
\end{tabular}

Article 4.1: '... reach global peaking of greenhouse gas emissions as soon as possible... undertake rapid reductions thereafter in accordance with best available science... achieve a balance between anthropogenic emissions by sources and removals by sinks of greenhouse gases...'.

Article 7.1: 'Parties hereby establish the global goal on adaptation of enhancing adaptive capacity, strengthening resilience and reducing vulnerability to climate change, with a view to contributing to sustainable development and ensuring an adequate adaptation response...'

Article 10: 'Parties share a longterm vision on the importance of fully realizing technology development and transfer in order to improve resilience to climate change and to reduce greenhouse gas emissions.'

\section{Contribution of geoscience to article}

Exploring for and extracting fossil fuels with a lower carbon impact; researching and implementing Carbon Capture and Storage (CCS); investigating geothermal energy sources; and working to develop geological disposal for radioactive waste from nuclear power stations.

For secure food production, geoscience is essential to (i) the mapping and understanding of groundwater resources to maintain water security for agriculture, (ii) mineral extraction for fertilizer, and (iii) mapping of soil quality.

Globally we need to reduce greenhouse gas emissions to a point where there is a sustainable balance between gas emission and sequestration. This can be through both natural carbon sinks and CCS implementation. Locating suitable reservoirs and characterizing these for $\mathrm{CO} 2$ sequestration over large timescales will require geoscience expertise in stages of design, testing, and implementation.

Geoscientists support research into climatelinked hazards (e.g., flooding, landslides, drought). Engineering, hydro- and structural geology are essential for effective siting of infrastructure and homes. Long-term monitoring data (e.g., slope movement) can be used to inform new development. Geologists' understanding of climate change in the deep past, and its impact on environments can inform mitigation and resilience strategies.

The technical capacity required to realize the ambitions of the Paris Agreement will come, in part, from geoscientists. Cooperation is needed over areas such as technology transfer and knowledge exchange. Sharing of appropriate disciplinary knowledge across political and geographic borders will support the implementation of the Paris Agreement.

\section{Example Output}

Geological Disposal of Depleted, Natural and Low Enriched Uranium (RWM, 2016)

Soil type influences crop mineral composition in Malawi (Joy et al., 2015)

$\mathrm{CO} 2$ sequestration and storage capacity at Sleipner in the North Sea (BGS, 2017b).

Resilience assessment for geotechnical infrastructure assets (Shah et al., 2014)

Collaborative geoscience research, such as that funded by the UK

Government's Global Challenges Research Fund. 


\section{DISCUSSION}

In Sections 2-4, we describe geoscientists' role in the SDGs, SFDRR and Paris Agreement, noting the significant scope for geoscientists to engage in all three. Engagement can take many forms, as noted in Table 3. Here we outline four types of engagement, with examples of actual/potential activities associated with each. The examples in Table 3 are illustrative, rather than exhaustive, and intended to promote discussion. In the remainder of this section, we consider this diversity of engagement in the context of (i) our ethical responsibility to engage, (ii) catalyzing increased engagement, and (iii) ensuring effective engagement for maximum development impact.

\subsection{Ethical Responsibility to Engage}

The geoscience community have a professional and social responsibility to reflect on the engagement required to help deliver these frameworks. There is a professional responsibility as the geoscience sector must be equipped and ready to respond to the demands placed on us by government and industry. There is a social responsibility, as our failure to engage, or engage well, can limit what is achieved or reduce sustainability. Poor quality engagement (e.g., a weak understanding of the social context of a project, or limited dialogue with stakeholders) may detrimentally impact a project (Gill, 2016). We discuss this in Section 5.3.

The Cape Town Statement on Geoethics (Di Capua et al., 2016) includes a set of geoethical values that help to frame our responsibility to engage in global development frameworks. For example, it encourages sharing knowledge and a spirit of cooperation, and promotes geoeducation and outreach to further sustainable development. The broad range of organizations supporting the Cape Town Statement (e.g., American Geophysical Union, European Federation of Geologists, African Association of Women in Geosciences) is indicative of the widespread international support for an out- ward looking geoscience community.

\subsection{Catalyzing Increased Engagement}

Throughout this contribution, we have included examples of activities, projects, and publications that demonstrate existing engagement by the geoscience community in global development. There is scope, however, for this to expand (Lubchenco et al., 2015; Stewart and Gill, 2017), as illustrated by one example. Consider the engagement labelled 'Framework Promotion' in Tab. 3. The 2017 European Geosciences Union (EGU) General Assembly included 1059 scientific sessions and side events (EGU, 2017). In the session descriptions, only nine $(0.85 \%)$ of these 1059 sessions referred to the Sustainable Development Goals, five $(0.47 \%)$ to the Sendai Framework, and five $(0.47 \%)$ to the Paris Agreement or COP 21. The remaining 1040 $(>98 \%)$ sessions did not refer to any of the global frameworks, despite many being on pertinent topics. The proactive promotion of development frameworks, including in settings such as the EGU General Assembly, would help improve awareness and foster greater engagement. It would also demonstrate the role of geoscience to other disciplines and the broader policy-making community. Improved awareness could catalyze other types of engagement. For example, helping to shape new research questions, or improving research dissemination to policy makers.

\subsection{Effective Engagement}

Engagement must be effective, culturally appropriate, and sustainable. As previously noted, poor quality engagement can hinder development progress and does not serve society well. The Cape Town Statement on Geoethics (Di Capua et al., 2016) presents a helpful articulation of the necessary values if the geoscience sector is to make a full and positive contribution to the delivery of global development frameworks (e.g., honesty, integrity, competence, commitment to life-long-learning). 
Table 3: Types and Examples of Engagement.

\begin{tabular}{|c|c|c|c|}
\hline \multirow{2}{*}{ Type of Engagement } & \multicolumn{3}{|c|}{ Example of Engagement } \\
\hline & SFDRR & SDGs & Paris Agreement \\
\hline $\begin{array}{l}\text { A. Framework Design: } \\
\text { Informing the process that } \\
\text { determines what is in- } \\
\text { cluded, defining key } \\
\text { terms, determining indi- } \\
\text { cators of success. }\end{array}$ & $\begin{array}{l}\text { Submission (individual } \\
\text { or institutional) to } \\
\text { UNISDR Expert Work- } \\
\text { ing Group on Indicators } \\
\text { and Terminology. }\end{array}$ & $\begin{array}{l}\text { Early-career scientists } \\
\text { engaging with the UN } \\
\text { Major Group for Chil- } \\
\text { dren and Youth sub- } \\
\text { mission to SDG negotia- } \\
\text { tions. }\end{array}$ & $\begin{array}{l}\text { Research contributions } \\
\text { to IPCC assessment re- } \\
\text { ports (IPCC, 2013). }\end{array}$ \\
\hline $\begin{array}{l}\text { B. Framework Promotion: } \\
\text { Ensuring that members of } \\
\text { the geoscience community } \\
\text { are aware of the frame- } \\
\text { work, and potential geo- } \\
\text { science inputs. }\end{array}$ & $\begin{array}{l}\text { Panel discussion on } \\
\text { 'Geohazards: From Sendai } \\
\text { to the SDGs' at a GfGD } \\
\text { Conference. }\end{array}$ & $\begin{array}{l}\text { SDGs workshop at the } \\
\text { European Geosciences } \\
\text { Union General Assem- } \\
\text { bly. }\end{array}$ & $\begin{array}{l}\text { Joint Learned Societies' } \\
\text { 'Climate Communiqué' } \\
\text { (GSL, 2015). }\end{array}$ \\
\hline \multirow{2}{*}{$\begin{array}{l}\text { C. Framework Imple- } \\
\text { mentation: Research, out- } \\
\text { reach, and industry activi- } \\
\text { ties to support the suc- } \\
\text { cessful delivery of the } \\
\text { framework. }\end{array}$} & $\begin{array}{l}\text { Research: Triggered } \\
\text { landslides after the } 2015 \\
\text { M7.8 earthquake in Ne- } \\
\text { pal (BGS, 2017a). }\end{array}$ & $\begin{array}{l}\text { Research: 'Unlocking the } \\
\text { Potential of Groundwater } \\
\text { for the Poor' (UPGro, } \\
\text { 2017). }\end{array}$ & $\begin{array}{l}\text { Research: Carbon cap- } \\
\text { ture and storage } \\
\text { (NERC, 2017). }\end{array}$ \\
\hline & $\begin{array}{l}\text { Practice: Developing } \\
\text { tools to support earth- } \\
\text { quake education } \\
\text { (Parsquake, 2017). }\end{array}$ & $\begin{array}{l}\text { Practice: Construction } \\
\text { of sustainable water } \\
\text { points (e.g., boreholes) } \\
\text { and sanitation facilities. }\end{array}$ & $\begin{array}{l}\text { Research: Groundwater } \\
\text { resilience to climate } \\
\text { change in Africa (Mac- } \\
\text { Donald et al., 2011). }\end{array}$ \\
\hline $\begin{array}{l}\text { D. Framework Monitor- } \\
\text { ing and Evaluation: As- } \\
\text { sessing the efficacy of in- } \\
\text { terventions to support } \\
\text { implementation. }\end{array}$ & $\begin{array}{l}\text { Evaluation of landslide } \\
\text { education to assess its } \\
\text { impact on perceptions } \\
\text { of landslide triggering. }\end{array}$ & $\begin{array}{l}\text { Data collection on ac- } \\
\text { cess to geoscience train- } \\
\text { ing, monitoring pro- } \\
\text { gress on SDG } 5 \text { (gender } \\
\text { equality). }\end{array}$ & $\begin{array}{l}\text { Long-term monitoring } \\
\text { of ocean acidification } \\
\text { (IOCCP, 2017). }\end{array}$ \\
\hline
\end{tabular}

Professional and learned societies, such as the Geological Society of London (see www.geolsoc.org.uk), also play an important role in ensuring effective engagement through their focus on professionalism. Chartership and the emphasis on Continued Professional Development, encourages the geoscience workforce to reflect on the skills and experiences required to serve society.

Effective engagement is also rooted in understanding the science-policy-practice interface. This includes, for example, determining the information needs of stakeholders (e.g., policy makers, community groups, development NGOs), how they will use this information, and how best to present it to support policymakers. Translating geoscience knowledge into tools to support policy and practice requires dialogue and partnerships between geoscientists and other stakeholders (Lubchenco et al., 2015). Engaging diverse stakeholders early in the research-process helps to ensure a shared perception of the problem, defines data needs, and ultimately results in the production of useful knowledge (Weichselgartner and Kasperson, 2010).

Increased dialogue, critical to our contributions being relevant, may also require the geoscience community to invest in additional and complementary skills (Gill, 2016). The geoscience 
community readily embraces advances in technology, informatics, and other physical sciences to advance their science. In contrast, whereas cultural and ethical understanding, crossdisciplinary communication, and social science research approaches can also support effective engagement and enhance our science, they are rarely included in a geoscientist's education (Stewart and Gill, 2017). To engage with policymakers, for example, we should enhance our socio-political understanding (e.g., how government works), and recognize the complexity of policy-making and the role of science as one form of evidence in this process (Boyd, 2016; Gluckman, 2016).

Dissemination approaches may also need to change if geoscience engagement is to be most effective. Geoscientists are well trained in the skills required to collect, analyze and publish data in scientific journals, and present information at (geo)scientific conferences. These are important opportunities to communicate with other scientists, but may not be the most appropriate medium for communicating with other stakeholders (Marker, 2016). Priority for Action 1 of the SFDRR, for example, includes an objective 'promote the collection, analysis, management and use of relevant data and practical information and ensure its dissemination, taking into account the needs of different categories of users, as appropriate' (UNISDR, 2015). To realize this objective, we should embrace forms of communication other than the scientific journal, and be proactive at presenting information across disciplinary silos.

\section{CONCLUSIONS}

In this article, we have highlighted the role of geoscientists in three development frameworks, designed to address global priorities of sustainable development (SDGs), disaster risk reduction (SFDRR), and climate change (Paris Agreement). These frameworks offer the geoscience community an exciting opportunity for innovative research and application of our science. The successful implementation of these frameworks through 2015-30 will require in- creased engagement from the geoscience community. This engagement can take many forms, and we include in this contribution examples that demonstrate this broad scope. Common across all engagement is the need for it to be of the highest quality, embracing the values and skills required to work at the science-policypractice interface. A geoscience community that invests in the skills and understanding that are required for effective engagement is wellpositioned to help deliver a sustainable future.

\section{ACKNOWLEDGEMENTS}

This paper is the extended version of a contribution made at the 35th International Geological Congress, 2016 (Cape Town). We thank Martin Smith, Peter Bobrowsky and Giuseppe Di Capua for their comments and guidance, and Nic Bilham for supporting FB's contribution. This article is published with the permission of the Executive Director, British Geological Survey (NERC).

\section{REFERENCES}

Aitsi-Selmi, A., Murray, V., Wannous, C., Dickinson, C., Johnston, D., Kawasaki, A., Stevance, A.S. and Yeung, T. (2016). Reflections on a science and technology agenda for 21st century disaster risk reduction. International Journal of Disaster Risk Science, 7(1), 1-29.

BGS (2017a). Nepal earthquakes response. Available online: www.bgs.ac.uk/research/ earthHazards/epom/Nepalearthquakerespons e.html (accessed 4 September 2017).

BGS (2017b). CO2 storage: Sleipner field. Available online: www.bgs.ac.uk/science/ $\mathrm{CO} 2$ (accessed 4 September 2017)

Boucher, O., Bellassen, V., Benveniste, H., Ciais, P., Criqui, P., Guivarch, C., Le Treut, H., Mathy, S. and Séférian, R. (2016). Opinion: In the wake of Paris Agreement, scientists must embrace new directions for climate change research. Proceedings of the National Academy of Sciences, 113(27), 7287-7290.

Boyd, I.L. (2016). Take the long view. Nature, 540(7634), 520-521. 
Di Capua G., Peppoloni S., and Bobrowsky P. (2016). Cape Town Statement on Geoethics. With the contributions of Bilham N., Bohle M., Clay A., Lopera E.H., Mogk D. IAPG - International Association for Promoting Geoethics. Available online: www.geoethics.org/ctsg (accessed 4 Sep-tember 2017).

Duncan, M., Edwards, S., Kilburn, C., Twigg, J. (2016). An interrelated hazards approach to anticipating evolving risk. GFDRR (Ed.) The Making of a Riskier Future: How Our Decisions Are Shaping Future Disaster Risk, Global Facility for Disaster Reduction and Recovery, Washington, USA (2016), 114121.

EGU (2017). General Assembly Programme. Available online: https://www.egu2017.eu/ (accessed 4 September 2017).

Gill, J.C. (2016). Building good foundations: Skills for effective engagement in international development. Geological Society of America Special Papers, 520, 1-8.

Gill, J.C. (2017). Geology and the Sustainable Development Goals. Episodes, 40, 70-76.

Gluckman, P. (2016). The science-policy interface. Science, 353(6303), 969-969.

GSL (2010). Climate change: evidence from the geological record, Geological Society of London, $12 \mathrm{p}$.

IOCCP (2017). International Ocean Carbon Coordination Project - Ocean Acidification, Available online: www.ioccp.org/index.php/oceanacidification (accessed 4 September 2017).

IPCC (2013). The Physical Science Basis. Contribution of Working Group I to the Fifth Assessment Report of the Intergovernmental Panel on Climate Change [Stocker, T.F., D. Qin, G.-K. Plattner, M. Tignor, S.K. Allen, J. Boschung, A. Nauels, Y. Xia, V. Bex and P.M. Midgley (eds.)]. Cambridge University Press, Cambridge, United Kingdom and New York, NY, USA, 1535 p.

Joy, E.J., Broadley, M.R., Young, S.D., Black, C.R., Chilimba, A.D., Ander, E.L., Barlow, T.S. and Watts, M.J. (2015). Soil type influences crop mineral composition in Malawi. Science of the Total Environment, 505, 587-595.
Lubchenco, J., Barner, A. K., Cerny-Chipman, E. B., and Reimer, J. N. (2015). Sustainability rooted in science. Nature Geoscience, 8(7), 741-745.

MacDonald, A.M., Bonsor, H.C.; Calow, R.C.; Taylor, R.G.; Lapworth, D.J.; Maurice, L.; Tucker, J.; O Dochartaigh, B.E. (2011). Groundwater resilience to climate change in Africa. British Geological Survey Open Report 11/031, 32pp.

Mani, L., Cole, P.D., and Stewart, I. (2016). Using video games for volcanic hazard education and communication: an assessment of the method and preliminary results. Natural Hazards and Earth System Sciences, 16, 1673-1689.

Marker, B.R. (2016). Urban planning: the geoscience input. Geological Society, London, Engineering Geology Special Publications, 27(1), 35-43.

Mitchell, T., Guha-Sapir, D., Hall, J., Lovell, E., Muir-Wood, R., Norris, A., Scott, L. and Wallemacq, P. (2014). Setting, measuring and monitoring targets for reducing disaster risk. Recommendations for post-2015 international policy frameworks. ODI, $84 \mathrm{p}$.

NERC (2017). Carbon Capture and Storage Research Programme 2002-2014, Available online: www.nerc.ac.uk/research/funded/programme/cc s/ (accessed 4 September 2017).

Nilsson, M., Griggs, D. and Visbeck, M. (2016). Policy: map the interactions between Sustainable Development Goals. Nature, 534, 320-322.

Oven, K.J., Milledge, D.G., Densmore, A.L., Jones, H., Sargeant, S. and Datta, A. (2016). Earthquake science in DRR policy and practice in Nepal. ODI, 36 p.

Parsquake (2017). Earthquake education. Available online: www.parsquake.org (accessed 4 September 2017).

RWM (2016). Geological Disposal - Investigating the Implications of Managing Depleted, Natural and Low Enriched Uranium through Geological Disposal, Radioactive Waste Management NDA Report no. NDA/RWM/142, 131 p. 
Shah, J., Jefferson, I. and Hunt, D.V.L. (2014). Resilience Assessment for Geotechnical Infrastructure Assets. Proc. Institute of Civil Engineers: Asset Management.

Spangenberg, J.H. (2017). Hot Air or Comprehensive Progress? A Critical Assessment of the SDGs. Sustainable Development, 25(4), 311-321.

Stewart, I.S., and Gill, J.C. (2017). Social geology - integrating sustainability concepts into Earth sciences. Proceedings of the Geologists' Association, 128(2), 165-172.

UN (2015a). Transforming Our World: The 2030 Agenda for Sustainable Development: United Nations, Geneva, 35 p.

UN (2015b). The Paris Agreement, United Nations, Geneva, $27 \mathrm{p}$.
UNISDR (2015). Sendai Framework for Disaster Risk Reduction, United Nations, Geneva, $37 \mathrm{p}$.

UNISDR (2017). DRR Terminology, Available online: www.unisdr.org/we/inform/terminology (accessed 4 September 2017).

UPGro (2017). https://upgro.org/ (accessed 4 September 2017).

Weichselgartner, J. and Kasperson, R. (2010). Barriers in the science-policy-practice interface: Toward a knowledge-action-system in global environmental change research. Global Environmental Change, 20(2), 266277. 